\title{
IMPLEMENTASI MANAJEMEN STRATEGI MELALUI BALANCED SCORECARD PADA UMKM AMELIA SNACK DAN COOKIES
}

\author{
Siti Maharani Chairunnisa ${ }^{1}$, Afia Salsabila ${ }^{2}$, Arnita Rahmawaty Aziza ${ }^{3}$, Siti Rahmah $^{4}$ \\ IPB University ${ }^{1,2,3}$, Universitas Mulawarman ${ }^{4}$

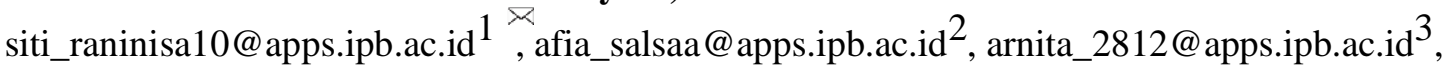 \\ siti.rahmah572@tamu.unsoed.ac.id ${ }^{4}$
}

\begin{abstract}
ABSTRAK
UMKM yang berperan penting dalam perekonomian dan penyerapan tenaga kerja masih mengalami beberapa kendala. Manajemen strategi yang tepat diperlukan untuk mengatasi hal tersebut. Paper ini bertujuan untuk mengidentifikasi permasalahan, merumuskan indikator kinerja utama, dan memformulasikan strategi dengan menggunakan balanced scorecard pada salah satu UMKM makanan ringan di wilayah Bekasi. Perumusan bisnis proses dilakukan dengan aliran supplier, input, process, output, dan customer (SIPOC). Penelitian ini menggunakan analisis kuantitatif den ${ }^{1}$ gan mengambil objek penelitian yaitu UMKM Amelia Snack dan Cookies. Data yang digunakan merupakan data primer bersumber dari kuesioner pairwise comparison dan wawancara terstruktur dengan pemilik UMKM, observasi langsung, serta didukung oleh data sekunder berupa studi literatur. Metode pengolahan dan analisis data dilakukan dengan menyusun fishbone diagram, Indikator Kinerja Utama (IKU), dan balanced scorecard yang terdiri dari empat sasaran yaitu keuangan, pelanggan, internal bisnis, serta pertumbuhan dan pembelajaran. Hasil penelitian menunjukkan bahwa UMKM Amelia Snack dan Cookies memiliki tingkat balanced scorecard yang rendah pada perspektif pertumbuhan dan pembelajaran yaitu kepuasan dan kompetensi karyawan. Selain itu, memiliki tingkat baik dalam ketiga perspektif lainnya. Perumusan paket kompensasi yang tepat, pelatihan yang tepat, dan pemasaran terpadu dapat dilakukan sebagai strategi pengembangan UMKM. Sementara itu, integrasi semua perspektif diperlukan untuk strategi keberlanjutan UMKM Amelia Snack dan Cookies.
\end{abstract}

Kata kunci: Balanced Scorecard, Manajemen Strategi, Pengukuran Kinerja, UMKM

\begin{abstract}
MSMEs, which had an essential role in the economy and employment, are still experiencing several obstacles. Proper strategic management is needed to overcome it. This paper aims to identify problems, formulate key performance indicators, and develop strategies using the balanced scorecard in one of the snack food SMEs in Bekasi. The business process formulation uses the flow of suppliers, inputs, processes, outputs, and customers (SIPOC). This study uses quantitative analysis by taking Amelia Snack dan Cookies as a research object. The primary data was sourced from pairwise comparison questionnaires and structured interviews with owners, direct observation, and
\end{abstract}

$\overline{1} \rtimes$ Corresponding author: Siti Maharani Chairunnisa (siti_raninisa10@apps.ipb.ac.id) 
supported by secondary data in the form of literature studies. Data processing is carried out by compiling. Fishbone diagrams, key performance indicators, and a balanced scorecard consist of four targets: finance, learning and growth, customer, and internal business. The results showed that Amelia Snack and Cookies had a low level of balanced scorecard in the learning and growth perspective. In addition, it has good levels in the other three views. Formulating the right compensation package, the proper training, and integrated marketing can be done as a development strategy. Meanwhile, the integration of all perspectives is needed for sustainability strategy.

Keywords: Balanced Scorecard, MSMEs, Performance Measurement, Strategic Management

\section{PENDAHULUAN}

Perubahan yang terus terjadi di berbagai aspek kehidupan mulai menuntut setiap elemen untuk beradatasi dalam menghadapinya. Perekonomian sebagai penunjang keberlangsungan setiap negara tidak luput dari perkembangan dan perubahan. Setiap pelaku usaha perlu memiliki keunggulan kompetitif ditengah perubahan dan ketidakpastian yang terus terjadi. Usaha Mikro Kecil dan Menengah (UMKM) memainkan peran yang penting dalam perekonomian (Todorov \& Smallbone, 2014). Hal ini sejalan dengan (Ghobadian \& Gallear, 1996) yang mengemukakan bahwa usaha mikro memiliki kemungkinan untuk bertahan dengan lingkungan yang tidak stabil dibandingkan dengan organisasi dengan birokrasi yang besar, dimana inovasi dan fleksibilitas untuk beradaptasi terhadap perubahan baru adalah faktor kunci. Struktur yang mendatar dan rendahnya hierarki yang ada pada usaha mikro dan kecil membuat para top management dapat lebih melakukan kerja yang fleksibel dan membangun hubungan personal yang kuat dengan karyawan.

Peranan UMKM tentu dirasakan pula oleh setiap negara tanpa terkecuali. Sebagai contoh, usaha kecil di India berkontriubusi sekitar 30\% dengan secara konsisten menunjukkan tingkat perkembangan yang meningkat dari tahun ke tahun (Todorov \& Smallbone, 2014). Hal ini sejalan dengan (Hongal et al., 2017) yang menyebutkan bahwa UMKM merupakan sektor yang sudah terbukti sebagai sektor dengan kinerja baik dalam lima dekade terakhir. Keberadaan UMKM dinilai dapat berkontribusi pada penciptaan lapangan kerja, industrialisasi, hingga pendapatan nasional. Di lain sisi, UMKM juga memiliki peran yang strategis dan signifikan pada perekonomian di negara Malaysia. Hal ini sejalan dengan (Suprapto et al., 2009) yang menyebutkan bahwa UMKM secara progresif berkembang sebagai mesin pertumbuhan pada perekonomian Malaysia. UMKM secara signifikan berkontribusi pada aspek sosial-ekonomis dan infrastruktur.

Usaha mikro kecil menengah (UMKM) telah mulai berkembang pesat di Indonesia. UKM tumbuh pesat jumlahnya semenjak krisis ekonomi tahun 1997 yaitu pada saat banyak terjadinya PHK oleh industri-industri menengah dan besar akibat krisis yang berkepanjangan sehingga orang yang di PHK akhirnya mengembangkan usaha secara mandiri baik membuka usaha penjualan, pengolahan maupun jasa (Wahyuningsih, 2009). Berdasarkan (BPS, 2008), pasca krisis ekonomi jumlah UMKM tidak berkurang, dan terus tumbuh hingga mampu menyerap dua per tiga dari banyaknya seluruh tenaga kerja di sektor industri yaitu sebesar 62,17\%. Dapat dikatakan bahwa 99,21\% ekonomi dipengaruhi oleh pelaku UMKM sementara sekitar 0,79\% merupakan usaha berskala sedang dan besar.

Dari keseluruhan UMKM yang ada, dapat diklasifikasikan ke dalam beberapa sektor salah satunya UMKM sektor makanan dan minuman. Adapun data pesebaran UMKM sektor makanan terbanyak yang didasarkan pada provinsi, dapat dilihat pada Gambar1. 


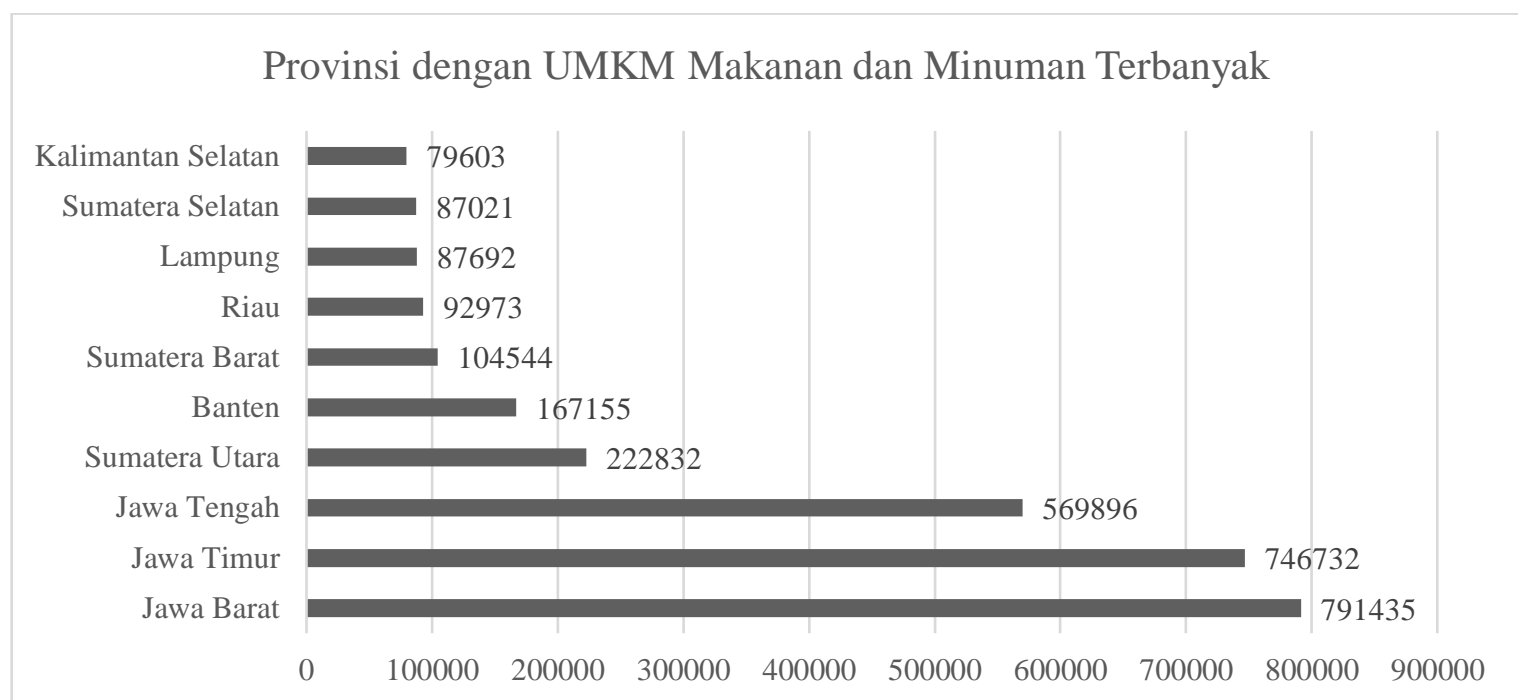

Gambar 1: Provinsi dengan Jumlah UMK Sektor Makanan dan Minuman Terbanyak Sumber: data diolah (BPS, 2021)

Provinsi yang memiliki jumlah UMKM sektor makanan dan minuman terbanyak adalah Provinsi Jawa Barat sebanyak 791.435 unit, diikuti oleh Jawa Timur dan Jawa Tengah yang masin-masing sebesar 746.732 unit dan 569.896 unit. Sementara, tujuh provinsi lain yang termasuk 10 besar dalam jumlah UMKM sektor makanan dan minuman terbanyak yaitu Provinsi Sumatera Utara, Banten, Sumatera Barat, Riau, Lampung, Sumatera Selatan, dan Kalimantan Selatan.

Provinsi Jawa Barat yang menduduki peringkat pertama berdasar jumlah UMKM pada sektor makanan dan minuman cukup menarik untuk diteliti. Dengan demikian, pada penelitian ini akan dibahas mengenai salah satu UMKM sektor makanan dan minuman yang secara spesifik berada pada bidang makanan ringan pada wilayah Bekasi yaitu UMKM Amelia Snack dan Cookies. Amelia Snack dan Cookies telah berdiri sejak tahun 2014. Amelia snack dan Cookies mempunyai spesialisasi dan keunggulan dalam proses pembuatannya, karena terbuat dari bahan-bahan yg berkualitas, bersifat homemade dan tentunya memastikan aspek kebersihan. Adapun produk makanan yang dijual oleh UMKM ini merupakan cemilan khas daerah seperti kembang goyang dan akar kelapa. Hal ini yang menjadi keunikan dari Amelia Snack dan Cookies. UKM ini terus melakukan inovasi sehingga dapat menghasilkan produk yang bervariasi seperti stick yang terbuat dari berbagai macam sayuran dan bahan lainnya.

Sebagai UMKM yang masih aktif beroperasi, Amelia Snack dan Cookies juga tentunya menghadapi berbagai permasalahan yang ada. Jika dilihat dalam klasifikasi permasalahan UMKM berdasarkan (Setyobudi, 2007), UMKM memliki permasalahan dasar (basic problem) yang berkaitan dengan sumber daya manusia, aspek keuangan, hingga pengelolaan internal bisnis yang masih perlu ditingkatkan.

Teknik identifikasi permasalahan dan penyusunan strategi UKM diperlukan agar kendala yang terjadi dapat diatasi dan tidak menghambat perkembangan UKM. Metode balanced scorecard merupakan salah satu metode strategi pengembangan UKM yang dapat digunakan untuk mengatasi masalah tersebut dengan terlebih dahulu menyusun fishbone dan key performance indicator. Oleh karena itu, tujuan dari penelitian ini adalah untuk mengidentifikasi permasalahan, merumuskan indikator kinerja utama, dan memformulasikan 
strategi dengan menggunakan balanced scorecard pada salah satu UKM makanan ringan di wilayah Bekasi.

\section{KAJIAN LITERATUR}

\section{Manajemen Strategi}

Manajemen strategi terdiri dari analisis, keputusan, dan tindakan organisasi yang dilakukan untuk menciptakan dan mempertahankan keunggulan kompetitif. Definisi ini menangkap dua elemen utama yang masuk ke jantung bidang manajemen strategis (Dess et al., 2014). Manajemen strategis berkaitan dengan analisis tujuan strategis (visi, misi, dan tujuan) bersama dengan analisis lingkungan internal dan eksternal organisasi atau perusahaan. Setelah analisis dilakukan, perusahaan harus mengambil keputusan terkait strategi yang cocok diterapkan pada perusahaan. Perusahaan harus dapat memperkirakan sumber daya yang dibutuhkan serta mengelola sumber daya yang dimiliki agar rencana strategi tersebut dapat diterapkan secara efektif dan efisien. Menurut (Dess et al., 2014), esensi dari manajemen strategis adalah studi tentang mengapa beberapa perusahaan mengungguli yang lain. Dengan demikian, manajer perlu menentukan bagaimana suatu perusahaan bersaing sehingga dapat memperoleh keuntungan yang berkelanjutan dalam jangka waktu yang lama (Dess et al., 2014).

Menurut (Yunus, 2016), manajemen strategis terdiri atas sembilan tugas penting. Pertama, dengan merumuskan misi perusahaan, termasuk pernyataan yang luas mengenai maksud filosofi, dan sasaran perusahaan. Kedua, dengan melakukan suatu analisis yang mencerminkan kondisi dan kapabilitas internal perusahaan. Ketiga, dengan menilai lingkungan eksternal perusahaan, termasuk faktor persaingan dan faktor kontekstual umum lainnya. Keempat, dengan menganalisis pilihan-pilihan yang dimiliki oleh perusahaan dengan cara menyesuaikan sumber dayanya dengan lingkungan eksternal. Kelima, dengan mengidentifikasi pilihan paling menguntungkan dengan cara mengevaluasi setiap pilihan berdasarkan misi perusahaan. Keenam, dengan memilih satu set tujuan jangka panjang dan strategi utama yang akan menghasilkan pilihan paling menguntungkan tersebut. Ketujuh, dengan mengembangkan tujuan tahunan dan strategi jangka pendek yang sesuai dengan tujuan jangka panjang dan strategi utama yang telah ditentukan. Kedelapan, dengan mengimplementasikan strategi yang telah dipilih melalui alokasi sumber daya yang dianggarkan, di mana penyesuaian antara tugas kerja, manusia, struktur, teknologi, dan sistem pernghargaan ditekankan. Terakhir, dengan mengevaluasi keberhasilan proses strategis sebagai masukan pengembalian keputusan di masa mendatang (Yunus, 2016).

\section{Usaha Mikro Kecil dan Menengah (UMKM)}

Dalam perekonomian suatu negara, peran pelaku kegiatan ekonomi memiliki posisi penting dalam kestabilan dan kelangsungan perekonomian. Pelaku ekonomi memiliki beberapa tingkatan yang dibagi berdasarkan skala usaha dan bisnis yang dilakukannya mulai dari usaha yang berskala mikro hingga usaha yang sudah berskala besar. Peranan Usaha Kecil dan Menengah sangat penting bagi perekonomian negara termasuk Indonesia. UMKM menjadi krusial perananya karena dianggap penyelamat perekonomian Indonesia di masa krisis pada periode 1992-2000 (Wahyuningsih, 2009).

Usaha Mikro Kecil dan Menengah (UMKM) merupakan salah satu bidang yang memberikan kontribusi yang signifikan dalam memacu pertumbuhan ekonomi Indonesia. Hal ini dikarenakan daya serap UMKM terhadap tenaga kerja yang sangat besar dan dekat dengan rakyat kecil. Statistik pekerja Indonesia menunjukan bahwa 99,5 \% tenaga kerja Indonesia bekerja di bidang UMKM (Jauhari, 2010). UMKM perlu dikembangkan dengan dilandasi beberapa alasan bahwa UMKM menyerap banyak tenaga kerja, memegang peranan penitng dalam ekspor nonmigas, dan memiliki urgensi dalam struktur ekonomi yang berbentuk 
piramida yang menunjukkan adanya ketimpangan yang lebar antara pemain kecil dan besar dalam perekonomian Indonesia.

\section{Visi dan Misi}

Visi merupakan tujuan jangka panjang perusahaan atau organisasi untuk dicapai pada masa depan. Visi sebuah organisasi adalah pandangan umum dari cita-cita yang ingin diwujudkan oleh organisasi tersebut atau dapat dikatakan bahwa visi merupakan pernyataan want to be dari organisasi (Yunus, 2016). Sedangkan misi merupakan langkah-langkah yang dapat ditempuh oleh perusahaan atau organisasi untuk mencapai visi. Misi harus mencakup tujuan utama organisasi dan harus memiliki batasan yang jelas, mengandung hal yang diharapkan oleh semua anggota, serta harus dapat digunakan untuk membantu proses evaluasi organisasi (Yunus, 2016). Manfaat dari penyusunan visi dan misi adalah perusahaan dapat memotivasi anggotanya untuk mewujudkan kondisi perusahaan yang baik di masa depan serta perusahaan dapat lebih mudah menyusun strategi yang tepat untuk mencapai cita-cita tersebut.

\section{Diagram Fishbone}

Diagram fishbone merupakan diagram sebab akibat. Pada diagram ini, penyebab masalah dan hasil yang ditimbulkannya diidentifikasi dan dianalisis. Diagram ini digunakan untuk melihat masalah apa saja yang timbul pada suatu proses atau kegiatan. Analisis digambarkan seperti bentuk tulang ikan yang terdapat kepala dan kerangka durinya. Menurut (Devi, 2016), diagram sebab akibat ini dapat digunakan untuk mengetahui kebutuhankebutuhan yang mencakup pengidentifikasian akar penyebab suatu permasalahan, pembangkitan ide-ide untuk solusi suatu masalah, serta penyelidikan atau pencarian fakta lebih lanjut dalam suatu permasalahan.

Diagram fishbone merupakan suatu alat visual untuk mengidentifikasi, mengeksplorasi, dan secara grafik menggambarkan secara detail semua penyebab yang berhubungan dengan suatu permasalahan (Asmoko, 2013). Permasalahan mendasar diletakkan pada bagian kepala diagram kemudian penyebab-penyebab masalah dianalisis pada bagian durinya. Kategori penyebab permasalahan yang sering digunakan sebagai start awal meliputi materials (bahan baku), machines and equipment (mesin dan peralatan), manpower (sumber daya manusia), methods (metode), mother naturelenvironment (lingkungan), dan measurement (pengukuran) (Asmoko, 2013). Kategori penyebab permasalahan pada fishbone sering disingkat sebagai 6M.

Adapun langkah-langkah yang digunakan dalam menganalisis permasalahan pada diagram fishbone yaitu sebagai berikut (Asmoko, 2013); membuat kerangka diagram fishbone; merumuskan masalah utama; mencari faktor-faktor utama yang berpengaruh atau berakibat pada permasalahan; menemukan penyebab untuk masing-masing kelompok penyebab masalah; menggambarkan penyebab-penyebab masalah tersebut pada diagram.

\section{Metode Balanced Scorecard}

Metode Balanced scorecard pertama kali dikemukakan oleh (Kaplan \& Norton, 2004). Balanced scorecard merupakan alat untuk merumuskan strategi perusahaan sehingga perusahaan dapat memutuskan untuk melakukan aksi yang tepat. Balanced scorecard melengkapi ukuran keuangan kinerja masa lalu dengan ukuran pendorong kinerja masa depan (Kaplan \& Norton, 2004). Balanced scorecard menerjemahkan misi dan strategi bisnis menjadi tujuan dan pengukuran yang nyata. Pengukuran merepresentasikan keseimbangan antara pengukuran eksternal untuk pemangku kepentingan dan pelanggan dengan pengukuran internal dari proses bisnis kritis, inovasi, serta pembelajaran dan pertumbuhan (Kaplan \& Norton, 2004). Metode balanced scorecard digunakan perusahaan sebagai sistem manajemen strategi jangka 
panjang. Perusahaan menggunakan pengukuran scorecard untuk menyelesaikan proses manajemen kritis yang mencakup; memperjelas dan menerjemahkan visi dan strategi; mengkomunikasikan dan menghubungkan tujuan dan pengukuran strategis; merencanakan, menetapkan target, dan meluruskan inisiatif strategis; serta menambah umpan balik dan pembelajaran strategis (Kaplan \& Norton, 2004).

Tujuan dan pengukuran pada metode balanced scorecard didasarkan pada visi dan strategi perusahaan. Tujuan dan pengukuran melihat kinerja organisasi dari empat perspektif yaitu perspektif keuangan, perspektif pelanggan, perspektif proses bisnis internal, serta perspektif pembelajaran dan pertumbuhan (Kaplan \& Norton, 2004). Menurut Rompho (2020), dalam setiap perspektif, ada empat elemen utama yang perlu dipertimbangkan. Elemen pertama adalah tujuan strategis yang disusun dengan alat bantu peta strategi. Peta strategi adalah alat yang membuat strategi lebih transparan dan nyata (Rompho, 2020). Elemen kedua yaitu ukuran kinerja. Setiap tujuan strategis dalam peta strategi harus dapat diukur (Rompho, 2020). Elemen ketiga yaitu sasaran atau target nilai. Setiap ukuran kinerja harus digabungkan dengan target nilai yang ingin dicapai organisasi. Elemen terakhir yaitu inisiatif strategi yaitu kegiatan yang perlu dilakukan organisasi untuk mencapai tujuannya yang disajikan dalam peta strategi (Rompho, 2020).

Balanced scorecard menyertakan perspektif keuangan karena ukuran keuangan memiliki nilai dalam meringkas konsekuensi ekonomi yang dapat diukur dari tindakan yang telah diambil (Kaplan \& Norton, 2004). Ukuran keuangan berhubungan dengan keuntungan dan variabel finansial lainnya dalam perusahaan. Pada perspektif pelanggan, manajer mengidentifikasi pelanggan dan segmen pasar pada unit bisnis dan pengukuran kinerja bisnis unit pada segmen target tersebut (Kaplan \& Norton, 2004). Salah satu ukuran yang dapat digunakan dalam perspektif pelanggan yaitu kepuasan pelanggan. Pada perspektif proses internal bisnis, pemangku kepentingan mengidentifikasi proses internal yang harus diungguli oleh perusahaan. Proses tersebut memungkinkan bisnis untuk menyampaikan proposisi nilai yang akan menarik dan mempertahankan pelanggan pada segmen target pasar serta memenuhi ekspektasi atau harapan pemangku kepentingan dalam pengembalian keuangan yang baik (Kaplan \& Norton, 2004)

Perspektif keempat yaitu pembelajaran dan pertumbuhan. Perspektif ini mengidentifikasi infrastruktur yang harus dibangun oleh perusahaan untuk membuat pertumbuhan dan improvement jangka panjang (Kaplan \& Norton, 2004). Pespektif ini menentukan faktor kunci yang paling kritis untuk kelangsungan perusahaan pada masa sekarang atau masa depan. Peta strategi balanced scorecard disusun setelah tujuan dan sasaran perusahaan telah ditetapkan. Peta strategi memberikan kerangka kerja untuk menggambarkan bagaimana strategi menghubungkan aset tak berwujud dengan proses penciptaan nilai (Kaplan \& Norton, 2004). Strategi menggambarkan logika strategi, menunjukkan dengan jelas tujuan untuk proses internal kritis yang menciptakan nilai dan aset tidak berwujud yang diperlukan untuk mendukungnya.

Balanced Scorecard menerjemahkan tujuan peta strategi menjadi ukuran dan target. Penelitian sebelumnya yaitu (Kaplan \& Norton, 2004) telah menemukan bahwa empat langkah diperlukan untuk menggunakan scorecard dalam proses perencanaan strategis dan penganggaran operasional jangka panjang yang terintegrasi. Pertama, menetapkan target peregangan. Manajer harus menetapkan target ambisius untuk langkah-langkah yang dapat diterima oleh semua karyawan. Hubungan sebab-akibat dalam scorecard membantu mengidentifikasi pendorong penting yang akan memungkinkan kinerja pada ukuran hasil yang penting, terutama finansial dan pelanggan. Kedua, mengidentifikasi dan merasionalisasi inisiatif strategis. Kesenjangan antara target ambisius yang ditetapkan untuk ukuran scorecard dan kinerja saat ini pada ukuran tersebut memungkinkan manajer untuk menetapkan prioritas untuk investasi modal dan program tindakan yang dimaksudkan untuk menutup kesenjangan. 
Ketiga, mengidentifikasi inisiatif lintas bisnis yang kritis. Manajer mengidentifikasi inisiatif yang akan memberikan manfaat (sinergi) untuk tujuan strategis unit bisnis lain atau induk perusahaan. Terakhir, menautkan ke alokasi dan anggaran sumber daya tahunan. Manajer menghubungkan rencana strategis tiga sampai lima tahun dengan pengeluaran diskresioner dan kinerja yang dianggarkan untuk tahun mendatang. Hal ini memungkinkan untuk melacak lintasan unit bisnis di sepanjang perjalanan strategisnya.

\section{METODE PENELITIAN}

Penelitian ini merupakan penelitian kuantitatif dengan mengambil objek penelitian yaitu UKM Amelia Snack dan Cookies yang berlokasi di wilayah Bekasi. Adapun proses penelitian dapat dilihat pada Gambar 2. Penelitian diawali dengan merumuskan proses bisnis yang terjadi pada Amelia Snack dan Cookies menggunakan analisis terhadap supplier, input, process, output, dan outcome (SIPOC). Setelah dirumuskan proses bisnis, kemudian dilakukan identifikasi masalah pada UKM yang menggunakan analisis tulang ikan (fishbone analysis). Kemudian, dilanjutkan dengan perumusan strategi yang dilakukan menggunakan pendekatan balanced scorecard. Sumber data penelitian yang digunakan terdiri dari sumber data primer yang didapat dari kuesioner pairwise comparison, observasi langsung dan wawancara terstruktur dengan pemilik UKM serta sumber data sekunder didapat dari kajian literatur dan laporan UKM yang menunjang penelitian. Waktu penelitian dilakukan pada rentang waktu September hingga November 2021.

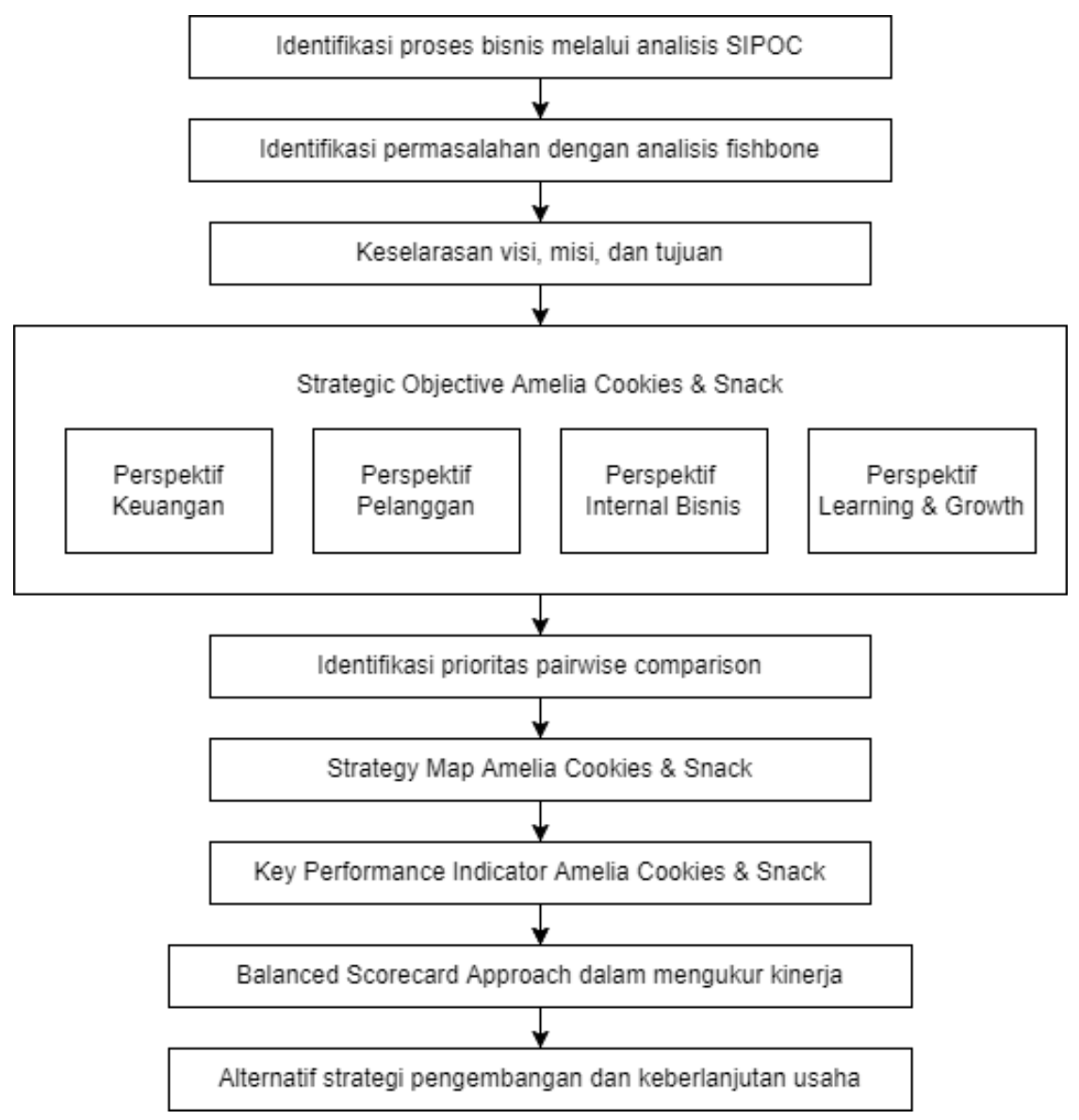

Gambar 2: Proses Penelitian 


\section{HASIL PENELITIAN DAN PEMBAHASAN}

Amelia Snack dan Cookies adalah brand makanan ringan yang telah berdiri sejak tahun 2014. Amelia Snack dan Cookies terletak di Gg Hj. Tekel, Jatiluhur, Jatiasih, Bekasi. UKM ini menjual makanan ringan khas daerah seperti kembang goyang dan akar kelapa. Selain itu, terdapat beberapa varian produk kue kering yang ditawarkan. Hal ini yang menjadi keunikan dari Amelia Snack dan Cookies. UKM ini senantiasa berusaha untuk melakukan inovasi sehingga dapat menghasilkan produk yang bervariasi dan menjangkau lebih banyak target konsumen. Pembelian produk ini dapat dilakukan dengan beberapa cara yaitu bisa datang langsung ke toko, pesan melalui whatsapp, dan melalui g-ofood. Dalam menjalankan aktivitas bisnisnya, setiap usaha tentu perlu memiliki hierarki yang menjadi acuan untuk alur operasi usaha. Adapun Amelia Snack dan Cookies memiliki struktur organisasi yang dapat dilihat pada Gambar 3 .

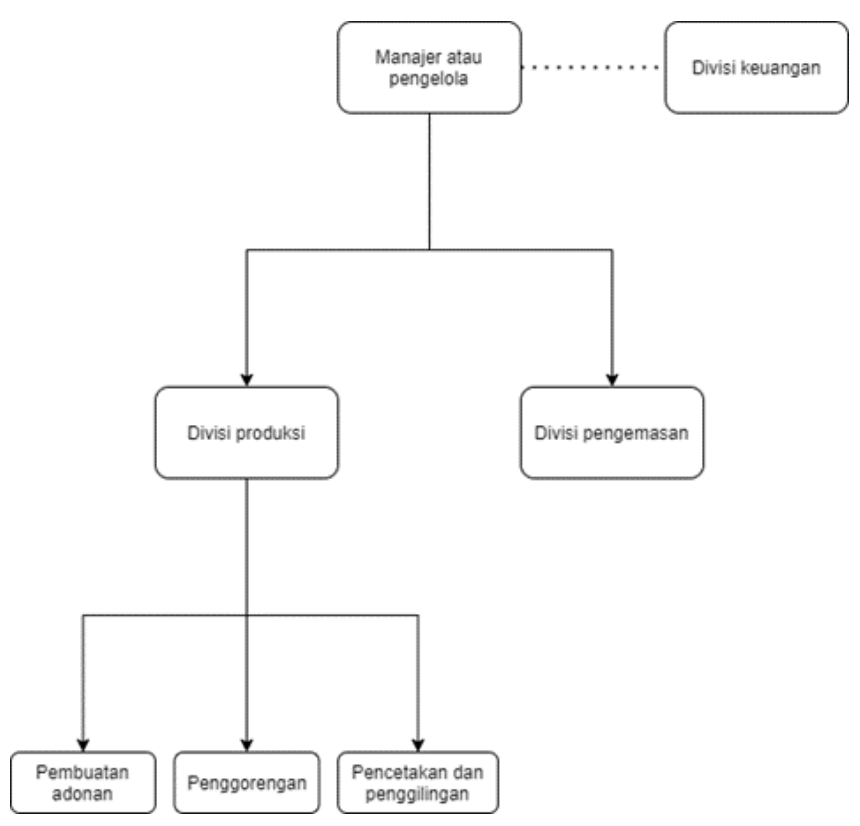

Gambar 3: Struktur Organisasi Amelia Snack dan Cookies

Secara struktur, Amelia Snack dan Cookies dikelola oleh seorang manager yang membawahi tiga divisi yaitu divisi pengemasan, divisi produksi, dan divisi keuangan. Dalam divisi produksi terdapat pembagian kedalam tiga sub-divisi yaitu pembuatan adonan, penggorengan, dan pencetakan serta penggilingan. Dalam menjalankan usahanya, Amelia Snack dan Cookies juga melibatkan supplier sebagai pemasok bahan baku. Hal tersebut dapat dilihat pada diagram gambaran proses Gambar 4.

Pada penggambaran proses bisnis UKM Amelia Snack dan Cookies dilakukan menggunakan pendekatan supplier, input, process, output, dan customer (SIPOC). Elemen yang berperan sebagai pemasok pada proses bisnis UKM ini yaitu toko bahan baku, toko plastik, dan toko Alat Tulis Kantor (ATK). Input yang terlibat dalam proses bisnis di UKM ini berupa bahan baku pembuatan produk, mesin produksi dan mesin pengemas, peralatan dapur, dan sumber daya manusia. Adapun proses yang terjadi pada rangkaian SIPOC diawali dengan penyiapan alat dan bahan, pembuatan bahan adonan, penggilingan dan pencetakan adonan, penggorengan dan pemanggangan, pengemasan, hingga pengiriman serta penjualan di outlet. Output yang akan dihasilkan yaitu berupa produk kue kering dan snack seperti kembang goyang, akar kelapa, stick aneka rasa, keripik pisang, keripik bawang, dan kue kering. Pelanggan atau customer yang disasar dalam proses bisnis ini adalah pelanggan langsung dan reseller kue kering serta snack. 


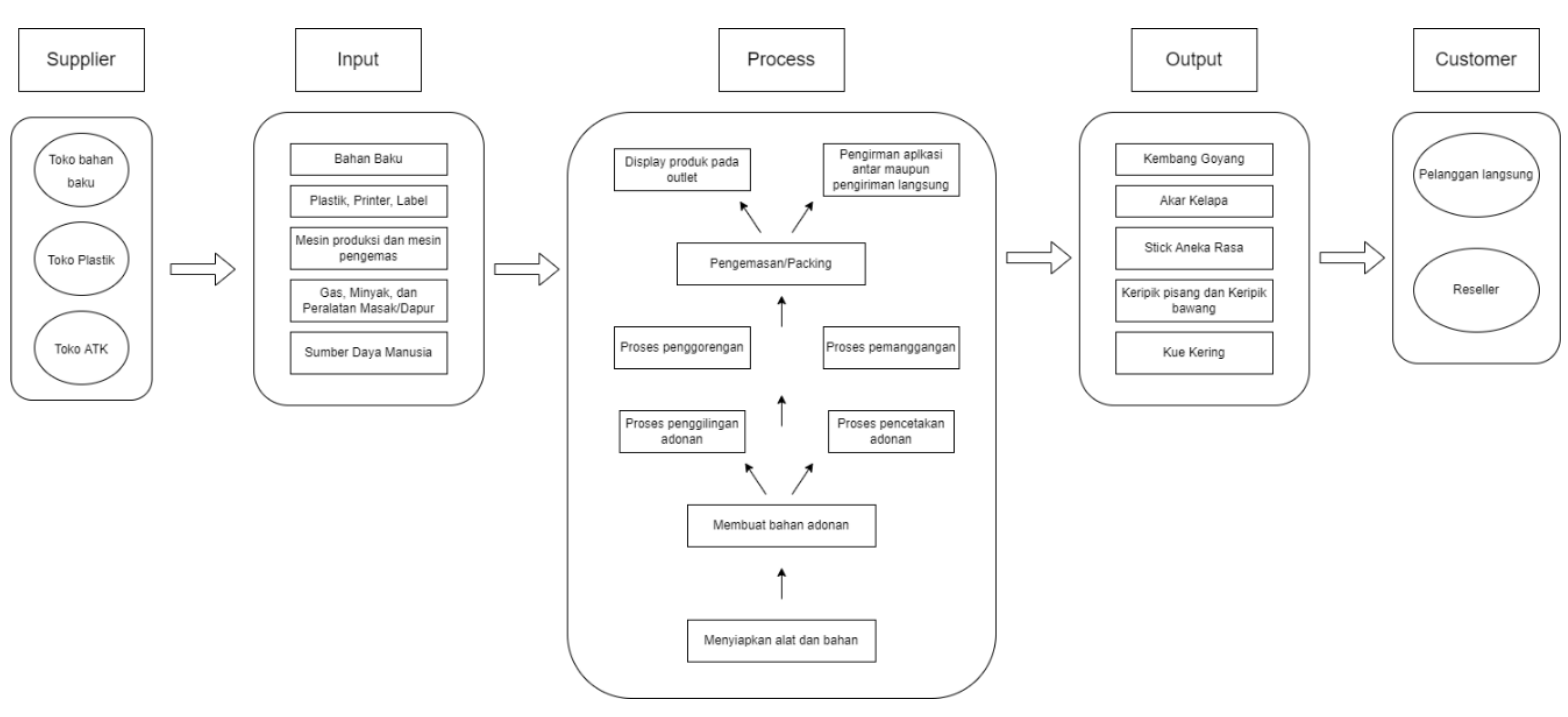

Gambar 4: Diagram SIPOC

\section{Identifikasi permasalahan}

Dalam kegiatan bisnisnya, Amelia Snack dan Cookies mengalami beberapa permasalahan yang muncul. Permasalahan yang ada pada UMKM diidentifikasi menggunakan fishbone analysis. Hasil identifikasi permasalahan dapat dilihat pad Gambar 5. Permasalahan yang terdapat pada UKM Amelia Snack dan Cookies dapat diklasifikasikan kedalam enam hal yang mencakup man, method, money, material, market, dan machine. Permasalahan yang menyangkut sumber daya manusia yaitu adanya kompetensi karyawan yang masih minim dan kepuasan karyawan yang cukup rendah. Selain itu, belum ter standardisasi nya alur kerja dan metode kerja menjadi permasalahan di UKM. Dari sisi keuangan, total profit dan total penjualan masih dapat ditingkatkan untuk keberlanjutan usaha. Biaya operasional yang cukup tinggi juga menjadi permasalahan yang perlu diselesaikan di UKM. Permasalahan lain yang terjadi di UKM yaitu inovasi produk yang masih terbatas, ketidakefektifan penggunaan mesin produksi, jumlah reseller yang masih sedikit, kepuasan pelanggan yang stagnan, serta media distribusi penjualan yang masih sedikit.

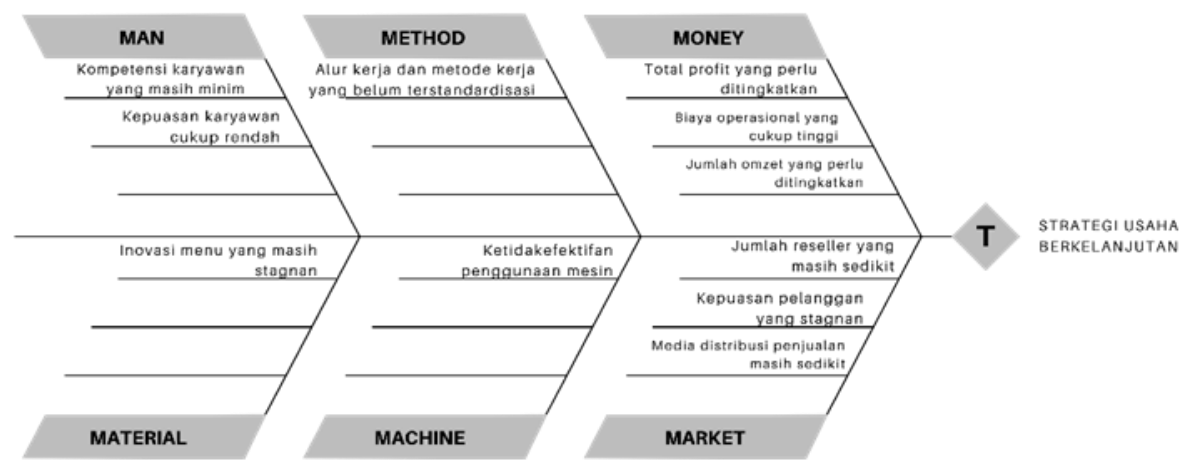

Gambar 5: Identifikasi Fishbone Analysis

\section{Perumusan balanced scorecard}

Dalam pertumbuhan pasar yang terus terjadi, menuntut setiap pelaku usaha untuk mampu memiliki keunggulan kompetitifnya masing-masing baik dari pelaku usaha besar hingga lingkup mikro dan kecil sekalipun. Hal ini membuat setiap perusahaan untuk mampu 
meningkatkan kinerja usahanya setiap periode. Pengukuran kinerja yang baik dan tersistematis akan mempermudah perusahaan dalam pengawasan target capaian dan tujuannya. Maka dari itu, penerapan suatu model pengukuran kinerja yang baik sangat dibutuhkan bagi perusahaan. Salah satu metode yang dapat diterapkan dalam pengukuran kinerja adalah Balanced Scorecard (BSC) (Witanti \& Hadiana, 2016).

Metode ini sudah cukup banyak diterapkan di berbagai perusahaan yang sudah terstruktur dan dapat dikatakan berskala besar. Masih sedikit usaha mikro dan kecil yang menggunakan metode balanced scorecard ini dalam pengukuran kinerjanya (Madsen, 2015). Sebagai usaha yang cenderung fleksibel dan dinamis, UMKM perlu untuk menjalankan pengukuran kinerja yang lebih komprehensif dalam mengembangkan bisnisnya (Costa et al., 2019). Sebagai usaha mikro dan kecil, Amelia Snack dan Cookies membutuhkan metode pengukuran kinerja yang baik. Perumusan balanced scorecard pada Amelia Snack dan Cookies diawali dengan mensinergikan antara visi, misi, tujuan, dan sasaran perspektif pada balanced scorecard yang terdiri dari perspektif keuangan, pelanggan, internal bisnis, pertumbuhan dan pembelajaran. Kemudian akan dirumuskan indikator kinerja utama yang akan membantu mengelaborasi sasaran dari keempat perspektif. Alokasi perspektif berdasar pairwise comparison oleh pemilik akan dijadikan input dalam pembuatan strategy map yang pada akhirnya akan mempengaruhi pembobotan pada pengkuran kinerja di scorecard akhir. Berdasarkan hasil wawancara dan diskusi terkait penyusunan visi, misi, tujuan, dan sasaran bisnis dengan pemilik Amelia Snack dan Cookies, diperoleh hasil alignment sebagai berikut.

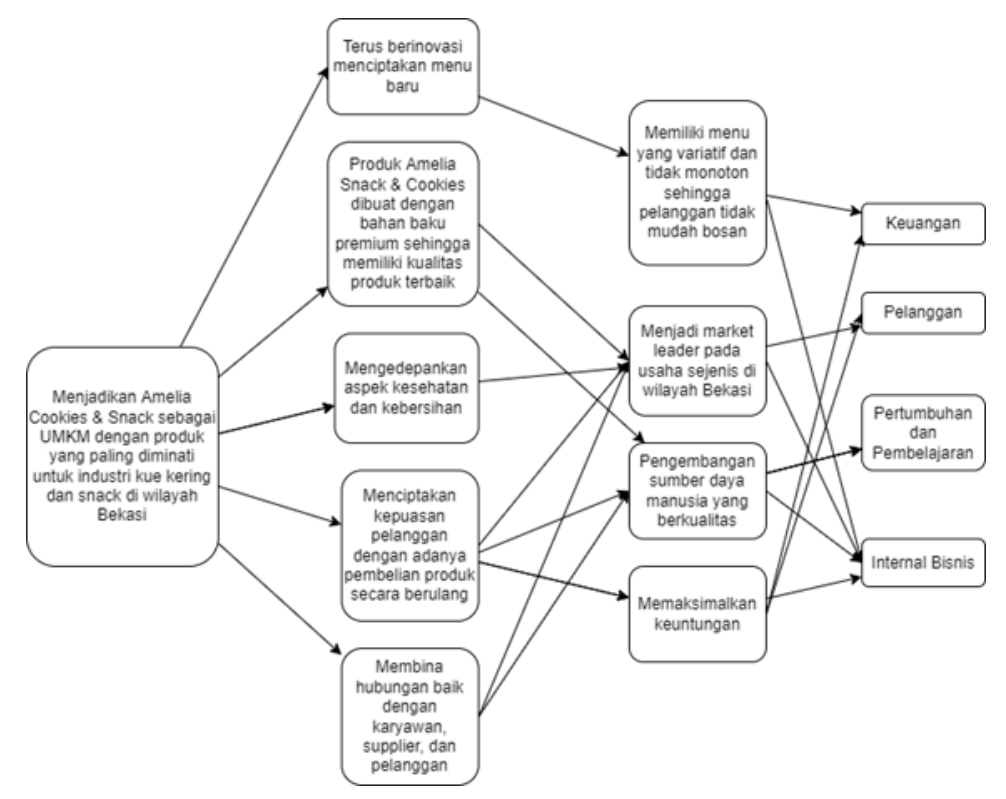

Gambar 6: Alignment Visi, Misi, Tujuan, dan Sasaran

Amelia Snack dan Cookies memiliki visi yang ingin dicapai yaitu "menjadikan Amelia Snack dan Cookies sebagai UMKM dengan produk yang paling diminati untuk industri kue kering dan snack di wilayah Bekasi". Adapun visi tersebut dielaborasikan dengan lima misi yang berbeda. Kelima misi tersebut dijelaskan dalam empat tujuan bisnis yang juga dikaitkan dengan keempat perspektif balanced scorecard.

Sasaran pada perspektif balanced scorecard akan dijadikan acuan dalam pembuatan inidkator kinerja utama bagi UMKM. Berdasarkan empat perspektif yaitu keuangan, pelanggan, internal bisnis, serta pertumbuhan dan pembelajaran, dapat dirumuskan indikator kinerja utama yang ingin dicapai oleh UMKM. Adapun perumusan indikator kinerja utama dapat dilihat pada Tabel 1. 
Dari keempat perspektif sasaran dapat dirumuskan menjadi beberapa indikator kinerja utama yang dapat menunjuang ketercapaiannya. Perspektif keuangan dijabarkan dengan jumlah penjualan, total keuntungan, dan biaya operasional. Perspektif pelanggan dijabarkan dengan tingkat kepuasan pelanggan dan total reseller. Perspekif pertumbuhan dan pembelajaran dijabarkan dengan tingkat kepuasan kerja karyawan dan tingkat kompetensi karyawan. Perspektif internal bisnis dijabarkan dengan jenis menu, media penjualan, dan kesesuaian Standard Operating Procedure (SOP). Setiap indikator kinerja utama pun diperlukan alokasi penanggung jawab dari struktur organisasi untuk memaksimalkan implementasi dan pengawasan setiap butir nya. Keseluruhan indikator kinerja utama dari keempat perspektif disusun berdasarkan konsep SMART-C yaitu Specific, Measurable, Agreeable, Realistic, Time- bounded, dan Continuously-improved.

Setelah dilakukan penyusunan indikator kinerja utama kedalam empat perspektif balanced scorecard dilakukan pembobotan prioritas perspektif tersebut. Adapun pemilihan prioritas dilakukan dengan pembobotan berbasis pairwise comparison berdasar pendapat dan pertimbangan pemilik UMKM. Prioritas sasaran perspektif dapat dilihat dari Tabel 2.

Tabel 1. Perumusan indikator kinerja utama

\begin{tabular}{|c|c|c|c|c|}
\hline Target & No & Detail & $\begin{array}{c}\text { Indikator Kinerja } \\
\text { Utama }\end{array}$ & $\begin{array}{c}\text { Struktur } \\
\text { Organisasi }\end{array}$ \\
\hline \multirow[t]{3}{*}{ Keuangan } & 1 & $\begin{array}{c}\text { Jumlah penjualan yang } \\
\text { dilakukan }\end{array}$ & $\begin{array}{l}\text { Jumlah omzet yang } \\
\text { didapatkan per tahun }\end{array}$ & Manajer \\
\hline & 2 & Peningkatan total profit & $\begin{array}{l}\text { Laba bersih yang } \\
\text { diterima per tahun }\end{array}$ & Manajer \\
\hline & 3 & Pengurangan biaya operasional & $\begin{array}{c}\text { Total biaya } \\
\text { operasional per } \\
\text { tahun }\end{array}$ & $\begin{array}{c}\text { Manajer dan } \\
\text { Divisi Keuangan }\end{array}$ \\
\hline \multirow[t]{2}{*}{ Pelanggan } & 1 & Tingkat kepuasan pelanggan & $\begin{array}{l}\text { Total rating aplikasi } \\
\text { antar makanan per } \\
\text { tahun }\end{array}$ & $\begin{array}{l}\text { Manajer dan } \\
\text { Seluruh } \\
\text { Karyawan }\end{array}$ \\
\hline & 2 & Total reseller & $\begin{array}{c}\text { Jumlah reseller baru } \\
\text { yang bergabung per } \\
\text { tahun }\end{array}$ & $\begin{array}{l}\text { Manajer dan } \\
\text { Seluruh } \\
\text { Karyawan }\end{array}$ \\
\hline \multirow{2}{*}{$\begin{array}{c}\text { Pertumbuhan } \\
\text { dan } \\
\text { Pembelajaran }\end{array}$} & 1 & $\begin{array}{c}\text { Tingkat kepuasan kerja } \\
\text { karyawan }\end{array}$ & $\begin{array}{l}\text { Tingkat turnover } \\
\text { karyawan per tahun }\end{array}$ & Manajer \\
\hline & 2 & Tingkat kompetensi karyawan & $\begin{array}{l}\text { Jumlah pelatihan } \\
\text { yang diikuti per } \\
\text { tahun }\end{array}$ & Manajer \\
\hline \multirow[t]{3}{*}{$\begin{array}{l}\text { Internal } \\
\text { Bisnis }\end{array}$} & 1 & Jenis menu yang ditawarkan & $\begin{array}{c}\text { Jumlah inovasi } \\
\text { produk beru yang } \\
\text { ditawarkan per tahun }\end{array}$ & $\begin{array}{c}\text { Manajer dan } \\
\text { Divisi Produksi }\end{array}$ \\
\hline & 2 & Media penjualan & $\begin{array}{c}\text { Jumlah penambahan } \\
\text { media penjualan } \\
\text { yang digunakan per } \\
\text { tahun }\end{array}$ & $\begin{array}{l}\text { Manajer dan } \\
\text { Divisi } \\
\text { Pengemasan }\end{array}$ \\
\hline & 3 & Kesesuaian SOP yang dilakukan & $\begin{array}{c}\text { Persentase } \\
\text { kesesuaian SOP } \\
\text { yang dilakukan per } \\
\text { tahun }\end{array}$ & $\begin{array}{l}\text { Manajer dan } \\
\text { Seluruh } \\
\text { Karyawan }\end{array}$ \\
\hline
\end{tabular}

Sumber: data diolah 
Tabel 2. Identifikasi prioritas sasaran

\begin{tabular}{|l|c|c|c|c|c|c|c|}
\hline $\begin{array}{c}\text { Balanced Scorecard } \\
\text { Perspective }\end{array}$ & Keuangan & Pelanggan & $\begin{array}{c}\text { Internal } \\
\text { Bisnis }\end{array}$ & $\begin{array}{c}\text { Pertumbuhan } \\
\text { dan } \\
\text { Pembelajaran }\end{array}$ & \multicolumn{2}{|c|}{ B Bobot } & Peringkat \\
\hline Keuangan & 1 & 5 & 5 & 3 & 14 & 0.444915 & 1 \\
\hline Pelanggan & $1 / 5$ & 1 & 3 & 5 & 9.2 & 0.292373 & 2 \\
\hline Internal Bisnis & $1 / 5$ & $1 / 3$ & 1 & 5 & 6.533333 & 0.207627 & 3 \\
\hline $\begin{array}{l}\text { Perumbuhan dan } \\
\text { Pembelajaran }\end{array}$ & $1 / 3$ & $1 / 5$ & $1 / 5$ & 1 & 1.733333 & 0.055085 & 4 \\
\hline
\end{tabular}

Sumber: data diolah

Perhitungan prioritas dilakukan dengan memberikan skor pada masing-masing perspektif. Skoring dilakukan berdasarkan (Saaty, 1980) poin 1 dinilai jika kedua sasaran atau perspektif sama penting, poin 3 dinilai jika sasaran sedikit lebih penting dari sasaran lainnya, poin 5 dinilai jika sasaran jelas lebih penting, poin 7 dinilai jika sangat jelas lebih penting, poin 9 dinilai jika mutlak lebih penting, sementara poin 2,4,6, dan 8 dnilai jika ragu pada poin diatas. Berdasarkan pendapat dan pertimbangan pemiliki pada indikator kinerja utama dan sasaran yang peneliti ajukan, didapat bahwa sasaran keuangan menjadi prioritas utama bagi UMKM dengan bobot sebesar 0.45 diikuti dengan sasaran pelanggan dengan bobot 0.3 , kemudian internal bisnis dengan bobot 0.2 , dan sasaran pertumbuhan dan pembelajaran dengan bobot 0.05 . Sasaran keuangan yang menjadi prioritas utama dijadikan sebagai acuan dalam penyusunan strategy map dan scorecard. Adapun strategy map yang dapat dirumuskan berdasar prioritas sasaran yang ada dapat dilihat pada Gambar 4 .

strategy map dan scorecard. Adapun strategy map yang dapat dirumuskan berdasar prioritas sasaran yang ada dapat dilihat pada Gambar 7.

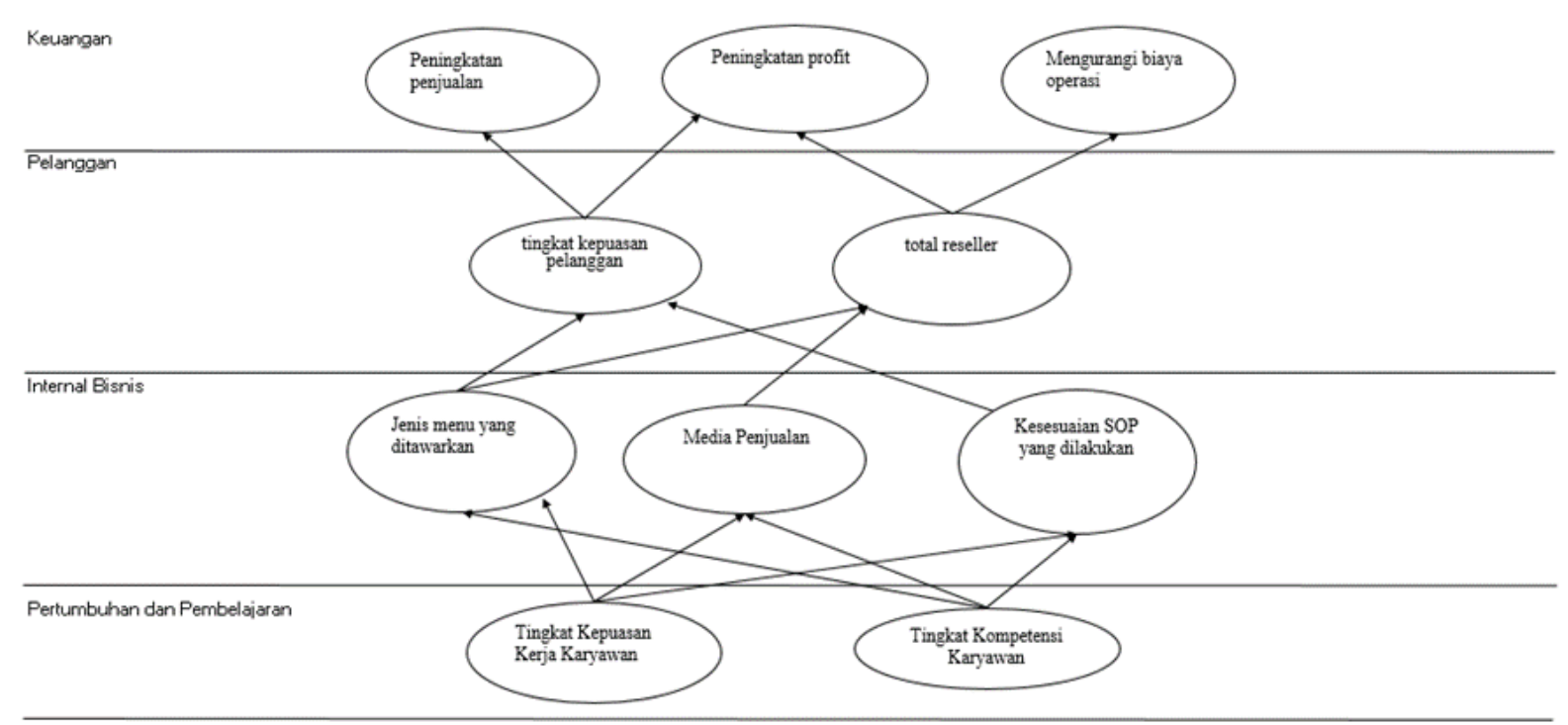

Gambar 7: Strategy Map

Sasaran keuangan berada di tingkat paling atas pada peta strategi berdasarkan prioritas sasaran. Lalu diikuti dengan sasaran pelanggan, internal bisnis, serta pertumbuhan dan pembelajaran. Elemen pada tiap sasaran saling dihubungkan sehingga tercipta peta strategi yang utuh. 
Setelah dilakukan tahapanan balanced scorecard yang diawali dengan mensinergikan visi, misi, tujuan, dan sasaran hingga pembuatan strategy map, dirumuskan scorecard yang akan digunakan dalam pengukuran kinerja UMKM Amelia Snack dan Cookies. Adapun scorecard dapat dilihat pada Tabel 3.

\section{Tabel 3. Balanced scorecard Amelia Snack dan Cookies}

\begin{tabular}{|c|c|c|c|c|c|c|c|c|c|c|c|}
\hline Perspective & Weight & $\begin{array}{l}\text { Strategic } \\
\text { Objectives }\end{array}$ & KPI & Weight & $\begin{array}{l}\text { Target } \\
2020\end{array}$ & $\begin{array}{l}\text { Realization } \\
2020\end{array}$ & Score & $\begin{array}{l}\text { Total } \\
\text { Score }\end{array}$ & $\begin{array}{l}\text { Strategic } \\
\text { Initiatives }\end{array}$ & PIC & Budget \\
\hline \multirow[t]{3}{*}{ Finance } & 0,27 & $\begin{array}{l}\text { Jumlah } \\
\text { penjualan }\end{array}$ & $\begin{array}{l}\text { Jumlah } \\
\text { omzet yang } \\
\text { didapatkan } \\
\text { per tahun }\end{array}$ & 0,09 & $500 \mathrm{~B}$ & $420 \mathrm{~B}$ & 1,19 & 1,08 & $\begin{array}{l}\text { Memasarkan } \\
\text { produk dengan } \\
\text { lebih } \\
\text { terintegrasi dan } \\
\text { Menawarkan } \\
\text { promosi } \\
\text { penjualan }\end{array}$ & Pengelola & 5B \\
\hline & & Total Profit & $\begin{array}{l}\text { Laba bersih } \\
\text { yang } \\
\text { diterima per } \\
\text { tahun }\end{array}$ & 0,09 & 150B & 120B & 1,25 & 0,11 & $\begin{array}{l}\text { Memasarkan } \\
\text { produk dengan } \\
\text { lebih } \\
\text { terintegrasi dan } \\
\text { Menawarkan } \\
\text { promosi } \\
\text { penjualan }\end{array}$ & Pengelola & \\
\hline & & $\begin{array}{l}\text { Pengurangan } \\
\text { biaya } \\
\text { operasional }\end{array}$ & $\begin{array}{l}\text { Total biaya } \\
\text { operasional } \\
\text { per tahun }\end{array}$ & 0,09 & $310 \mathrm{~B}$ & $300 \mathrm{~B}$ & 1,03 & 0,09 & $\begin{array}{l}\text { Memberdayakan } \\
\text { retail agar } \\
\text { menekan biaya } \\
\text { penyimpanan } \\
\text { serta mengatur } \\
\text { waktu lembur } \\
\text { karyawan }\end{array}$ & Pengelola & \\
\hline \multirow[t]{2}{*}{ Customer } & 0,36 & $\begin{array}{l}\text { Tingkat } \\
\text { Kepuasan } \\
\text { Pelanggan }\end{array}$ & $\begin{array}{l}\text { Total rating } \\
\text { aplikasi } \\
\text { antar } \\
\text { makanan }\end{array}$ & 0,18 & 4,3 & 4,4 & 0,977 & 0,175 & $\begin{array}{l}\text { Pelayanan yang } \\
\text { cepat dan } \\
\text { responsif } \\
\text { terhadap } \\
\text { keinginan } \\
\text { pelanggan serta } \\
\text { berusaha } \\
\text { menjaga cita } \\
\text { rasa makanan }\end{array}$ & Karyawan & \\
\hline & & Total reseller & $\begin{array}{l}\text { Jumlah } \\
\text { reseller baru } \\
\text { yang } \\
\text { bergabung } \\
\text { setiap tahun }\end{array}$ & 0,18 & 9 & 10 & 0,9 & 0,163 & $\begin{array}{l}\text { Memberikan } \\
\text { penawaran yang } \\
\text { sesuai agar } \\
\text { dapat menarik } \\
\text { minat reseller } \\
\text { serta menjamin } \\
\text { produk bisa } \\
\text { kompetitif di } \\
\text { pasar }\end{array}$ & Karyawan & \\
\hline \multirow[t]{3}{*}{$\begin{array}{l}\text { Internal } \\
\text { Business }\end{array}$} & 0,18 & $\begin{array}{l}\text { Jenis menu } \\
\text { yang } \\
\text { ditawarkan }\end{array}$ & $\begin{array}{l}\text { Jumlah } \\
\text { inovasi } \\
\text { produk yang } \\
\text { dilakukan } \\
\text { setiap tahun }\end{array}$ & 0,06 & 3 & 3 & 1 & 0,06 & $\begin{array}{l}\text { Melakukan riset } \\
\text { pasar untuk } \\
\text { mengetahui } \\
\text { keinginan } \\
\text { konsumen }\end{array}$ & $\begin{array}{l}\text { Pengelola } \\
\text { dan } \\
\text { Karyawan }\end{array}$ & $2 B$ \\
\hline & & $\begin{array}{l}\text { Media } \\
\text { penjualan }\end{array}$ & $\begin{array}{l}\text { Jumlah } \\
\text { penambahan } \\
\text { media } \\
\text { penjualan } \\
\text { yang } \\
\text { digunakan }\end{array}$ & 0,06 & 3 & 2 & 1,5 & 0,09 & $\begin{array}{l}\text { Melakukan riset } \\
\text { mengenai media } \\
\text { yang sesuai } \\
\text { untuk } \\
\text { memasarkan } \\
\text { produk }\end{array}$ & $\begin{array}{l}\text { Pengelola } \\
\text { dan } \\
\text { Karyawan }\end{array}$ & \\
\hline & & $\begin{array}{l}\text { Kesesuaian } \\
\text { SOP }\end{array}$ & $\begin{array}{l}\text { Persentase } \\
\text { kesesuaian } \\
\text { SOP yang } \\
\text { dilakukan } \\
\text { per tahun }\end{array}$ & 0,06 & $70 \%$ & $70 \%$ & $100 \%$ & 0,06 & $\begin{array}{l}\text { Melakukan } \\
\text { pengecekan } \\
\text { rutin dan } \\
\text { mencetak serta } \\
\text { menaruh SOP di } \\
\text { tempat yang } \\
\text { strategis terlihat } \\
\text { oleh karyawan }\end{array}$ & $\begin{array}{l}\text { Pengelola } \\
\text { atau } \\
\text { Manajer }\end{array}$ & \\
\hline $\begin{array}{l}\text { Learning } \\
\text { Growth }\end{array}$ & 0,18 & $\begin{array}{l}\text { Kepuasan } \\
\text { kerja } \\
\text { karyawan }\end{array}$ & $\begin{array}{l}\text { Tingkat } \\
\text { turnover } \\
\text { karyawan } \\
\text { per tahun }\end{array}$ & 0,09 & $40 \%$ & $44 \%$ & $110 \%$ & 0.099 & $\begin{array}{l}\text { Memberikan } \\
\text { kompensasi } \\
\text { yang sesuai } \\
\text { kepada }\end{array}$ & $\begin{array}{l}\text { Pengelola } \\
\text { atau } \\
\text { Manajer }\end{array}$ & $2,5 \mathrm{~B}$ \\
\hline
\end{tabular}


Tabel 3. Balanced scorecard Amelia Snack dan Cookies (Lanjutan)

\begin{tabular}{|c|c|c|c|c|c|c|c|c|}
\hline & & & & & & & $\begin{array}{l}\text { karyawan dapa } \\
\text { berbasis bonus } \\
\text { serta membuat } \\
\text { karyawan } \\
\text { nyaman } \\
\text { terhadap } \\
\text { lingkungan kerj }\end{array}$ & \\
\hline $\begin{array}{l}\text { Kompetensi } \\
\text { karyawan }\end{array}$ & $\begin{array}{l}\text { Jumlah } \\
\text { pelatihan } \\
\text { yang diikuti } \\
\text { per tahun }\end{array}$ & 0,09 & 2 & 0 & 0 & 0 & $\begin{array}{l}\text { Memberikan } \\
\text { pelatihan } \\
\text { kepada } \\
\text { karyawan dan } \\
\text { menyebarkan } \\
\text { informasi jika } \\
\text { ada pelatihan } \\
\text { sejenis yang } \\
\text { dibuka umum }\end{array}$ & $\begin{array}{l}\text { Pengelola } \\
\text { atau } \\
\text { Manajer }\end{array}$ \\
\hline
\end{tabular}

Berdasarkan penyusunan scorecard, didapatkan bahwa Amelia Snack dan Cookies memilki skor tertinggi untuk kinerja pada sasaran keuangan yaitu pada indikator kinerja utama jumlah penjualan dengan total skor 1,08. Skor tersebut didapatkan dengan perbandingan antara realisasi dan target yang disusun terkait realisasi omzet 420 juta rupiah dari target awal 500 juta rupiah. Sementara, skor terendah ada pada sasaran pertumbuhan dan pembelajaran yaitu pada indikator kinerja utama kompetensi karyawan yang masih memiliki skor 0. Hal ini karena pada UMKM tersebut masih belum ada wadah bagi karyawan untuk pelatihan maupun belum adanya karyawan yang pernah mengikuti pelatihan diluar perusahaan. Pada sasaran pelanggan, skor tertinggi ada pada kepuasan pelanggan yang dilihat dari total rating pada aplikasi antar makanan. Amelia Snack dan Cookies memiliki capaian realisasi rating pada aplikasi antar makanan sebesar 4,4 dari yang ditargetkan yaitu 4,3. Pada sasaran internal bisnis, skor tertinggi ada pada indikator kinerja utama media penjualan yang digunakan. Amelia Snack dan Cookies memiliki realisasi 2 media penjualan dari target 3 media penjualan.

Berdasarkan Tabel 3. tersebut menunjukkan secara keseluruhan bahwa perumusan strategi yang berbasis kinerja dapat dikategorikan menjadi dua yang mencakup strategi perbaikan dan strategi pengembangan. Sasaran yang termasuk dalam strategi perbaikan adalah pertumbuhan dan pembelajaran. Sementara, sasaran yang termasuk dalam strategi pengembangan adalah keuangan, pelanggan, serta internal bisnis.

Inisiatif strategi yang dapat dilakukan dari sasaran keuangan adalah dengan memasarkan produk dengan lebih terintegrasi dan menawarkan promosi penjualan dalam rangka strategi peningkatan keuntungan dan total penjualan. Sementara, memberdayakan retail agar menekan biaya penyimpanan serta mengatur waktu lembur karyawan dibutuhkan untuk menekan biaya operasional. Selanjutnya, dari sasaran konsumen diperlukan untuk melakukan pelayanan yang cepat dan responsif serta memberikan penawaran yang menarik konsumen. Kemudian, dari sasaran proses internal bisnis perlu dilakukan riset untuk media penjualan dan inovasi produk serta melakukan pengecekan Standard Operating Procedure (SOP) pada karyawan. Pemberian paket kompensasi dan pelatihan karyawan juga diperlukan untuk memenuhi sasaran pembelajaran dan pertumbuhan UMKM.

\section{KESIMPULAN}

Proses bisnis UMKM ini dilakukan dengan mengidentifikasi menggunakan pendekatan SIPOC yaitu supplier, input, process, output, dan customer. Tahapan untuk formulasi strategi pada UMKM diawali dengan pengidentifikasian masalah yang didapatkan bahwa untuk strategi keberlanjutan, UMKM masih memiliki permasalahan pada man, 
method, money, material, machine, dan market. Kemudian, dilanjutkan dengan perumusan visi, misi, tujuan, sasaran, dan indikator kinerja utama. Selanjutnya, dilakukan pembobotan berbasis pairwise comparison sebagai input prioritas dalam pemetaan strategi empat sasaran yaitu keuangan, pelanggan, internal bisnis, serta pertumbuhan dan pembelajaran. Pemetaan strategi yang telah dilakukan kemudian diperjelas dengan membuat scorecard indikator kinerja. Selanjutnya, diintegrasikan dengan strategi inisiatif dan budget dalam pencapaian kinerja utama. Berdasarkan keseluruhan hasil yang didapat yaitu menunjukkan bahwa pada UMKM Amelia Snack dan Cookies secara keseluruhan perumusan strategi yang berbasis kinerja dapat dikategorikan menjadi dua yang mencakup strategi perbaikan dan strategi pengembangan. Sasaran yang termasuk dalam strategi perbaikan adalah pertumbuhan dan pembelajaran. Sementara, sasaran yang termasuk dalam strategi pengembangan adalah keuangan, pelanggan, serta internal bisnis. Perumusan paket kompensasi yang tepat, pelatihan yang sesuai, dan pemasaran terintegrasi dapat dilakukan sebagai strategi pengembangan UKM. Sementara, integrasi keseluruhan perspektif diperlukan untuk strategi keberlanjutan pada UKM Amelia Snack dan Cookies.

\section{DAFTAR RUJUKAN}

Asmoko. (2013). Teknik ilustrasi masalah -. Hindri Asmoko, 1-8.

BPS. (2008). Profil Industri Mikro dan Kecil. In S. J. Indriati \& Irwanto (Eds.), BPS Indonesia. CV Ryan Indah.

BPS. (2021). Statistik Penyedia Makan Minum, 2019 (Direktorat Statistik Keuangan Teknologi Informasi dan Pariwisata (ed.)). Badan Pusat Statistik [BPS].

Costa, M. L. R. da, Giani, E. G. de S., \& Galdamez, E. V. C. (2019). Vision of the Balanced Scorecard in Micro, Small, Medium Enterprises. Systems and Management, 14(1), 131-141. https://doi.org/10.20985/1980-5160.2019.v14n1.1505

Dess, G., McNamara, G., Eisner, A., \& Lee, S. H. (2014). Strategic Management: Text and Cases. Mc Graw Hill Education.

Devi, R. S. (2016). Analisis Risiko Operasional PT. “XYZ.” In Jurnal Studi Manajemen dan Bisnis. Institiut Teknologi Sepuluh November.

Ghobadian, A., \& Gallear, D. N. (1996). Total quality management in SMEs. Omega, 24(1), 83-106. https://doi.org/10.1016/0305-0483(95)00055-0

Hongal, P., Charantimath, P., \& Phatak, G. G. (2017). Strategic Management in Indian MSMEs-

A Literature Review. International Journal of Management, IT and Engineering, 7(11), 152-178.

Jauhari, J. (2010). Upaya Pengembangan Usaha Kecil dan Menengah (UMKM) dengan Memanfaatkan E-Commerce. Jurnal Sistem Informasi, 2(1), 159-168.

Kaplan, R. S., \& Norton, D. P. (2004). Strategy Maps Converting Intangible Assets Into Tangible Outcomes (Harvard Bu). Harvard Business School Publishing Corporation.

Madsen, D. (2015). The Balanced Scorecard in the Context of SMEs: a Literature Review. Review of Business Research, 15(3), 75-86. https://doi.org/10.18374/rbr-15-3.8

Rompho, N. (2020). The Balanced Scorecard for School Management: Case Study of Thai Public Schools. Measuring Business Excellence, 24(3), 285-300. https://doi.org/10.1108/MBE-02-2019-0012

Saaty, T. L. (1980). The Analytic Hierarchy Process: Planning, Priority Setting, Resource Allocation. In Multi-Criteria Decision Analysis: Methods and Software. Mc Graw Hill, Inc. https://doi.org/10.1002/9781118644898.ch2

Setyobudi, A. (2007). Peran Serta Bank Indonesia Dalam Pengembanganusaha Mikro, Kecil Dan Menengah (UMKM). Buletin Hukum Perbankan Dan Kebanksentralan, 5(2), 29 35. 
Suprapto, B., Wahab, H. A., \& Wibowo, A. J. (2009). The Implementation of Balance Score Card for Performance Measurement in Small and Medium Enterprises: Evidence from Malaysian Health Care Services. The Asian Journal of Technology Management, 2(2), 76-87.

Todorov, K., \& Smallbone, D. (2014). Strategic Management Overview and SME in Globalized World. In L. Johnston, J. Yoder, A. de Marco, \& K. Wolfe (Eds.), Handbook of Research on Strategic Management in Small and Medium Enterprises (Issue January 2014, pp. 22-39). Business Science Reference (an imprint of IGI Global). https://doi.org/10.4018/978-1-4666-5962-9.ch002

Wahyuningsih, S. (2009). Peranan UKM Dlam Perekonomian Indonesia. Jurnal Ilmu - Ilmu Pertanian, 5(1), 1-14.

Witanti, W., \& Hadiana, A. I. (2016). Pengukuran Kinerja Pada Usaha Mikro Kecil Dan Menengah (UMKM) Dengan Balanced Scorecard (BSC). Jurnal Manajemen Informatika (JAMIKA), 6(2).

Yunus, E. (2016). Manajemen Strategis (A. A. Christian (ed.). CV Andi Offset. 